\title{
Physical chemistry evaluation of stability, spreadability, in vitro antioxidant, and photo-protective capacities of topical formulations containing Calendula officinalis L. leaf extract
}

\author{
Viviane Cecília Kessler Nunes Deuschle*, Regis Augusto Norbert Deuschle, Mariana Rocha \\ Bortoluzzi, Margareth Linde Athayde
}

Department of Industrial Pharmacy, Federal University of Santa Maria, Santa Maria, RS, Brazil

\begin{abstract}
Calendula is used widely in cosmetic formulations that present phenolic compounds in their chemical constitution. The objective of our research was to develop and evaluate the stability of topical formulations containing 5\% hydro-ethanolic extract of calendula leaves, including spreadability, and in vitro photoprotective, and antioxidant capacity. To evaluate the stability, we used organoleptic characteristics, $\mathrm{pH}$, and viscosity parameters. Antioxidant capacity was measured by the DPPH (2,2-diphenyl-1-picrylhydrazyl) method, and the photo-protective capacity by SPF spectrophotometric measure. All formulations were stable. The calendula extract formulations in gel and cream showed no significant variations in $\mathrm{pH}$, and the cream formulations presented lower viscosity variations than gel formulations. The spreadability of the gel formulations was superior to those in cream. The formulations also presented good antioxidant capacities and an FPS of around 1.75. In accordance with the results, the formulations can be used as antioxidants, but considering the low SPF obtained, calendula cannot be considered as a stand-alone sunscreen, yet may well be tested in future studies towards verifying enhancement of synthetic sunscreens.
\end{abstract}

Uniterms: Calendula officinalis L./pharmacognosy. Topical formulations/in vitro evaluation. Calendula/ topical formulations/in vitro evaluation.

A calêndula é amplamente utilizada em formulações cosméticas, apresentando compostos fenólicos em sua constituição química. Desta forma, o objetivo desta pesquisa foi desenvolver e avaliar a estabilidade de formulações tópicas contendo $5 \%$ de extrato hidroetanólico das folhas de calêndula, bem como a espalhabilidade, capacidade antioxidante e fotoprotetora in vitro nas mesmas. Para a avaliação da estabilidade, foram usados parâmetros como a verificação das características organolépticas, $\mathrm{pH}$ e viscosidade. A capacidade antioxidante foi verificada pelo método do DPPH (2,2-difenil,1- picril-hidrazila) e a capacidade fotoprotetora pela medida espectrofotométrica do FPS. Para as formulações testadas, observou-se que apresentaram uma boa estabilidade. As formulações de creme e gel com extrato de calêndula não apresentaram variações significativas nos valores de $\mathrm{pH}$ e o creme apresentou as menores variações de viscosidade em relação ao gel. A espalhabilidade das formulações de gel foi superior à do creme. As formulações também apresentaram uma boa capacidade antioxidante e um FPS em torno de 1.75. De acordo com os resultados, a formulação pode ser utilizada com ação antioxidante, porém com o FPS obtido, a calêndula não pode ser considerada um filtro solar isolado, mas poderá ser testada em estudos futuros para verificar a potencialização de filtros solares sintéticos.

Unitermos: Calendula officinalis L./farmacognosia. Formulações tópicas/avaliação in vitro. Calêndula/ formulações tópicas/avaliação in vitro.

\footnotetext{
*Correspondence: V. C. K. N. Deuschle. Department of Industrial Pharmacy, Center for Health Sciences, Santa Maria Federal University, 97105-900 - Santa Maria - RS, Brasil, Building 26, Room 1141. E-mail: vivianenunes1@yahoo.com.br
} 


\section{INTRODUCTION}

Calendula officinalis L. displays anti-inflammatory and antiseptic effects, and is used for various skin ulcerations and eczema. Decoctions and tinctures from the flowers have been used in preparations for burns, cuts, wounds, rashes, and bruises (Fonseca et al., 2010). Antifungal, anti-edema, and anti-diabetic activities are also described for this plant (Agatonovic-Kustrin, Loescher, 2013).

It is widely used in cosmetic formulations such as solar products due to its moisturizing properties. Extract from the flowers is used for its healing, and antiinflammatory activity in concentrations ranging from 1.0 to $2.0 \mathrm{~g}$ of dried flower, per $150 \mathrm{~mL}$ of water (CitadiniZanette, Negrelle, Borba, 2012).

Among the secondary metabolites already reported in the literature we find (flavonoids and phenolic acids), saponins, carotenoids, triterpenic alcohols, steroids, terpenoids, and triterpenoids (Butnariu, Coradini, 2012; Agatonovic-Kustrin, Loescher, 2013), which may be related to its antioxidant capacity.

Skin aging is a process that can be influenced by genetic, environmental, and behavioral factors. Aging has intrinsic (chronological), and extrinsic causes, and among these, the main cause is solar radiation (Ribeiro, 2010). It is known that the skin is the organ where aging effects are most prominent, occurring gradually over the human body. Among the many theories attempting to explain the aging process, one of the most suitable refers to the production of free radicals (Mariotti, Frasson, 2011). The process of skin aging is accelerated by several factors, the most common being harmful effects caused by UV radiation, which can favor the production of extremely harmful reactive oxygen species (ROS), and significantly reduce endogenous antioxidants. This facilitates attacks on important cell structures such as membranes, proteins, carbohydrates, and nucleic acids (Souza, Campos, Parcker, 2013). Considering these aspects, research and development of new antioxidant formulations, (in order to prevent and mitigate the effects of aging manifested on the skin surface) are an area of intense activity in cosmetology (Mariotti, Frasson, 2011).

Natural extracts in cosmetic formulations, designated as phytocosmetics, have been widely used, therefore requiring their characterization, and a taking into account of aspects related to their physical and chemical stability when incorporated into formulations. Tests of physical and chemical stability of phytocosmetics become important parameters that must be considered in the process of preparation, storage and application of the products formulated (Isaac et al., 2008).

Natural products may exhibit structural similarity to synthetic sunscreens, and can thus provide photoprotective action, and be used in formulations for this purpose or to potentiate the action of synthetic sunscreens. (Violante et al., 2009). Extracts rich in phenolic compounds, especially flavonoids, are being used in formulations containing UV filters. Due to their proven antioxidant and photo-protective action, these natural products can be used in such products in order to absorb radiation and neutralize free radicals, thus intensifying the protective effect. Other antioxidants are also reported as having this kind of activity, i.e. vitamins $\mathrm{E}$ and $\mathrm{C}$, tannins and alkaloids. (Souza, Campos, Parcker, 2013)

In this research, we aimed to develop cosmetic formulations in cream and gel form to incorporate hydroethanolic extract from the leaves of $C$. officinalis L., and to evaluate the resulting physical and chemical stability, spreadability, along with in vitro photo-protective and antioxidant capacity.

\section{MATERIAL AND METHODS}

The analysis was performed on a Shimadzu spectrophotometer (UV-1201), a Denver Instrument (Model UB-10) potentiometer, a Brookifield (Model1) viscometer, and a Centerbio (Model TDL 80-2B) centrifuge. All reagents used in this study were of analytical grade. The octyl stearate, butylhidrxytoluene (BHT), and parabens (methylparaben and propylparaben) were acquired from Galena. Self-emulsifying was non-ionic using disodium EDTA, imidazolidinyl urea, propyleneglycol and hidroxyethylcellulose which were acquired from Fagron.

\section{Extraction}

Leaves of Calendula officinalis L. were dried in an oven with air circulation $\left(45^{\circ} \mathrm{C}\right)$, crushed in a Wiley mill, and subjected to maceration with a hydroethanolic solvent (EtOH:H2O, 3:2, v/v), being subjected to daily manual agitation for a period of seven days (first maceration). The material was then filtered through cotton and concentrated on a rotary evaporator at a temperature below $40^{\circ} \mathrm{C}$, to eliminate the ethanol. The plant material was again covered with a further volume of the same solvent (second maceration). This second extraction liquid, after seven days, was filtered, concentrated and added to the first, thus obtaining the crude extract (Simões et al., 2010). Subsequently the extract was lyophilized for dryness. 
TABLE I - Composition of the cream based formulation (g)

\begin{tabular}{lc}
\hline Components & Amounts \\
\hline Oil Phase & \\
$\quad$ Octylstearate & $6.00 \mathrm{~g}$ \\
$\quad$ Self-emulsifying base nonionic (fatty alcohols and fatty acid esters of ethoxylate sorbitan) & $14.0 \mathrm{~g}$ \\
$\quad$ Butylhydroxytoluene (BHT) & $0.05 \mathrm{~g}$ \\
Aqueous phase & $0.05 \mathrm{~g}$ \\
$\quad$ Disodium EDTA & $\mathrm{qsp} 100 \mathrm{~mL}$ \\
$\quad$ Water & \\
Complementary phase & $3.30 \mathrm{~mL}$ \\
$\quad$ Preservative parabens (Propylparaben and methylparaben) & $0.60 \mathrm{~mL}$ \\
$\quad$ Preservative imidazolidinyl urea solution at 50\% &
\end{tabular}

\section{Preparation of formulations}

Hydroethanolic extract of Calendula officinalis $\mathrm{L}$. at $5 \%$ was incorporated into cream base formulations previously developed (Fonseca et al., 2010). The basis for incorporation of hydroethanolic extract of Calendula officinalis L. was formulated according to the Brazilian National Formulary (ANVISA, 2005), and the compositions are described in Tables I and II.

Formulations were designated as: CRBL (blank cream, without extract), CRC (calendula cream), GBL (blank gel, without extract), and GC (calendula gel). Preservative paraben solution was prepared as follows: propylparaben $(3 \mathrm{~g})$ and methylparaben $(6 \mathrm{~g})$ diluted in propylene glycol $(91 \mathrm{~mL})$ under heat.

TABLE II - Composition of the gel based formulation (g)

\begin{tabular}{lc}
\hline Components & Amounts \\
\hline Preservative parabens & $3.30 \mathrm{~g}$ \\
Propyleneglycol & $5.0 \mathrm{~g}$ \\
Dissodium EDTA & $0.1 \mathrm{~g}$ \\
Hydroxyethylcellulose & $2.0 \mathrm{~g}$ \\
Water & $\mathrm{qs} 100 \mathrm{~mL}$ \\
Imidazolidinyl urea preservative solution at & $0.60 \mathrm{~mL}$ \\
$50 \%$ & \\
\hline
\end{tabular}

The oil phase was heated to $75^{\circ} \mathrm{C}$, and the aqueous phase to $80^{\circ} \mathrm{C}$. The aqueous phase was then mixed into the oil phase under stirring. After cooling to approximately $40{ }^{\circ} \mathrm{C}$, the complementary phase was added.

EDTA and parabens solution were added to water and heated to $70{ }^{\circ} \mathrm{C}$. Hydroxymethylcellulose was then added to the solution under stirring until complete dispersion. After cooling to $40^{\circ} \mathrm{C}$, the imidazolidinyl urea solution was added.

\section{Stability evaluation}

The determination of the physical and chemical stability of the formulations was conducted in accordance with the Brazilian Cosmetic Products Stability Guide. Before the start of the stability tests, the National Health Surveillance Agency (ANVISA) recommends that the formulation is subjected to centrifugation test. For this purpose, the samples were centrifuged at $3000 \mathrm{rpm}$ for 30 minutes. After this test, the sample should remain stable, indicating that the product has been approved at this stage and may go forward to subsequent tests. For the next test, which lasted ninety days, the samples were submitted to heating in an oven $\left(50 \pm 2^{\circ} \mathrm{C}\right)$, cooling in refrigerator $\left(5 \pm 2{ }^{\circ} \mathrm{C}\right)$, and to room temperature $\left(25 \pm 2{ }^{\circ} \mathrm{C}\right)$ (ANVISA, 2004).

During this period organoleptic characteristics were determined following the scale given in table III (Mariotti, Frasson, 2011). The $\mathrm{pH}$ values were determined (in triplicate) by dispersing an aliquot of each formulation in distilled water $(10 \%, \mathrm{w} / \mathrm{v})$, and using a calibrated potentiometer. Viscosity was determined in a Brookfield rotational viscometer at room temperature $25 \pm 2{ }^{\circ} \mathrm{C}$ (using spindle 4 and speed 12), in triplicate. Results were expressed in centipoise $(\mathrm{cP})$. All readings were done at time zero and at 7, 15, 30, 60 and 90 days (ANVISA, 2004).

TABLE III - Scale to evaluate the organoleptic characteristics

\begin{tabular}{ll}
\hline 1 & No visible change - no change in color or appearance \\
2 & Mild loss of color \\
3 & Total loss of color \\
4 & Evidence of inconsistency and change in the appearance \\
\hline
\end{tabular}




\section{Spreadability determination}

This procedure was performed on samples at time zero and after 90 days, in triplicate, according to the methodology described by Knorst (1991). This method uses a circular mold plate of glass (diameter $=20 \mathrm{~cm}$, width $=0.2 \mathrm{~cm}$ ) with a central orifice of $1.2 \mathrm{~cm}$ diameter, which is placed on a glass support plate $(20 \mathrm{~cm} \times 20 \mathrm{~cm})$ positioned over millimetric graph paper.

Each sample was introduced into the orifice of the die plate and the surface leveled with a spatula. The plaque mold was carefully removed and a glass plate of known weight was placed over the sample. After one minute, the diameter in opposing positions (as covered by the sample) was read with the aid of the graph paper scale. Subsequently, we calculated the average diameter. This procedure was repeated successively adding other plates in one-minute intervals. The results were expressed as spreadability of the sample due to the applied weight, according to the equation below, which corresponds to the mean of three determinations.

$$
E i=d^{2} \frac{\pi}{4}
$$

where: $\mathrm{Ei}=$ spreadability of the sample weight for a given $\mathrm{i}\left(\mathrm{mm}^{2}\right) ; \mathrm{d}=$ diameter $(\mathrm{mm})$.

Spreadability factor $(\mathrm{S} f)$ was calculated using the following equation:

$$
S f=\frac{A}{W}
$$

where: $\mathrm{S} f=$ spreadability factor; $\mathrm{A}=$ total area $\left(\mathrm{mm}^{2}\right)$; $\mathrm{W}=$ total weight $(\mathrm{g})$.

\section{DPPH method determination of in vitro antioxidant capacity}

Antioxidant capacity was measured by the photocolorimetric DPPH (2,2-diphenyl 1-picrylhydrazyl) method according Mariotti and Frasson (2011). Samples were diluted at concentrations of $20,10,5,2.5$, and $1.25 \mathrm{mg} / \mathrm{mL}$ in methanol. Then $2.5 \mathrm{~mL}$ of each sample were added to $1 \mathrm{~mL}$ of a $0.3 \mathrm{mM}$ DPPH solution in methanol. After 30 minutes, the readings were made on a spectrophotometer at $517 \mathrm{~nm}$. A solution of $1 \mathrm{~mL}$ of $0.3 \mathrm{mM}$ DPPH in $2.5 \mathrm{~mL}$ of ethanol was used as a negative control and rutin cream and gel (at 5\%) were used as standards (positive control), at the same concentrations as the samples. Ethanol was used to zero the spectrophotometer, with the blank being the solutions of each sample, (without addition of DPPH). The assay was performed in triplicate, and antioxidant activity was calculated according the equation:

$\%$ inhibition $=\frac{100-[(\text { Abs sample }- \text { Abs blank }) \times 100]}{\text { Abscontrol }}$

where: Abs sample is the absorbance of the sample formulations; Abs blank is the absorbance of the blank formulations without additions of DPPH control; Abs control is the absorbance of DPPH solution in methanol.

A graph was made of percentage inhibition versus concentration of the extract.

Calculation of the inhibitory concentration $\left(\mathrm{IC}_{50}\right)$ was carried out using a line equation.

\section{Determination of the in vitro sun protection factor (in vitro SPF)}

The formulations were dissolved at a concentration of $0.2 \mu \mathrm{g} / \mathrm{mL}$ in ethanol, and read on a spectrophotometer from 290 to $320 \mathrm{~nm}$ with $5 \mathrm{~nm}$ intervals (Mansur et al., 1986). This procedure was performed on samples at time zero, and after 90 days, in triplicate. A cream and gel formulation with $7 \%$ octyl methoxycinnamate was used as standard. Calculation of SPF follows the equation:

$S P F($ spectrometry $)=C F \times \sum_{290}^{320} E E(\lambda) \times I(\lambda) \times a b s(\lambda)$

where: $\mathrm{CF}=$ correction factor $(=10)$, determined in accordance with two known SPF sunscreens such that a cream containing $8 \%$ resulted in SPF 4; EE $(\lambda)=$ erythemogenic effect radiation wavelength $(\lambda)$; I $(\lambda)=$ intensity of the sunlight at a given wavelength $(\lambda)$; Abs $(\lambda)=$ absorbance of the solution formulation containing sunscreen at a given wavelength $(\lambda)$.

The values of EE $(\lambda)$ and I $(\lambda)$ were previously calculated by Sayre et al. (1979) as described in table IV.

TABLE IV - Erythemogenic effect (EE) versus radiation intensity (I) according to the wavelength $(\lambda)$ (Sayre et al., 1979)

\begin{tabular}{cc}
\hline$\lambda(\mathrm{nm})$ & EE x I (normalized) \\
\hline 290 & 0.0150 \\
295 & 0.0817 \\
300 & 0.2874 \\
305 & 0.3278 \\
310 & 0.1864 \\
315 & 0.0839 \\
320 & 0.0180 \\
\hline
\end{tabular}

EE x I (normalized) = Erythemogenic effect $(E E)$ versus radiation intensity (I) 
TABLE V - Gel and cream organoleptic characteristics during the period of stability in days. (T0 - time zero; RT- room temperature; $\mathrm{O}$ - oven; R-refrigerator)

\begin{tabular}{|c|c|c|c|c|c|c|}
\hline Formulation/Time & T0 & 7 & 15 & 30 & 60 & 90 \\
\hline \multicolumn{7}{|l|}{ CRBL } \\
\hline RT & 1 & 1 & 1 & 1 & 1 & 1 \\
\hline $\mathrm{O}$ & 1 & 1 & 1 & 1 & 1 & 1 \\
\hline $\mathrm{R}$ & 1 & 1 & 1 & 1 & 1 & 1 \\
\hline \multicolumn{7}{|l|}{$\overline{\mathrm{CRC}}$} \\
\hline $\mathrm{RT}$ & 1 & 1 & 1 & 1 & 1 & 1 \\
\hline $\mathrm{O}$ & 1 & 1 & 1 & 2 & 2 & 2 \\
\hline $\mathrm{R}$ & 1 & 1 & 1 & 1 & 1 & 1 \\
\hline \multicolumn{7}{|l|}{ GBL } \\
\hline $\mathrm{RT}$ & 1 & 1 & 1 & 1 & 1 & 1 \\
\hline $\mathrm{O}$ & 1 & 1 & 1 & 1 & 1 & 1 \\
\hline $\mathrm{R}$ & 1 & 1 & 1 & 1 & 1 & 1 \\
\hline \multicolumn{7}{|l|}{$\overline{\mathrm{GC}}$} \\
\hline RT & 1 & 1 & 1 & 1 & 1 & 1 \\
\hline $\mathrm{O}$ & 1 & 1 & 1 & 1 & 2 & 2 \\
\hline $\mathrm{R}$ & 1 & 1 & 1 & 1 & 1 & 1 \\
\hline
\end{tabular}

1 No visible change-no change in color or appearance; 2 Mild loss of color. $(n=3)$

\section{Statistical analysis}

The results of the determinations were subjected to analysis of variance (ANOVA) followed by post hoc multiple comparison Tukey test $(p \leq 0.05)$. The analysis was performed using the Windows Excel 2007 program.

\section{RESULTS AND DISCUSSION}

After the initial centrifuge test, performed with the CRBL, CRC, GBL and GC, it was observed that all samples remained stable after centrifugation at 3000 rpm for 30 minutes. Organoleptic characteristics were evaluated during 90 days of storage and are described in table $\mathrm{V}$ according to the scale shown in Table III.

For consumer acceptance, stability studies of cosmetic formulations are essential to establish criteria for quality control, safety, and efficacy. Thus, these studies contribute to the development and improvement of formulations, establishing the validity, and monitoring physical, chemical, and microbiological characteristics (Isaac et al., 2008; Gonçalves, Campos, 2009).

At the beginning of the experiment, $\mathrm{CRC}$ and $\mathrm{GC}$ presented homogeneous aspect, greenish color, and a characteristic plant odor. During storage at different temperature conditions, it was observed that the color, appearance, and odor did not change, and are classified as " 1 " according to the scale used for organoleptic characteristics for the samples kept at room temperature and under refrigeration. Only the $\mathrm{CRC}$ and $\mathrm{GC}$ oven samples presented a mild loss of color after 30 and 60 days, respectively.

The $\mathrm{pH}$ determinations performed for the CRBL and $\mathrm{CRC}$ formulations are shown in Figure 1, and $\mathrm{pH}$ determinations for the GBL and GC formulations are shown in Figure 2.

Throughout the stability test, the cream formulations did not exhibit significant differences in their $\mathrm{pH}(p>0,05)$. With the gel formulations however, this difference was significant as compared with the blank $(p<0,05)$.

Results for viscosity evaluations, obtained as a function of time during storage stability testing are shown in Figure 3 to CRBL and CRC, and Figure 4 to GBL and GC.

The viscosity of a formulation will depend on its physicochemical characteristics, and on the temperature conditions to which it is subjected (Isaac et al., 2008). Evaluation of this parameter helps in determining the appropriate consistency and fluidity, and by indicating the performance of the product over time (ANVISA, 2004). For all cream samples, we observed a decrease in viscosity values, except in the CRCRT, which showed a slight increase at the end of 90 days. The difference was significant between samples, and when compared with blank $(p<0.05)$.

GC formulations showed a sharp drop in viscosity values as observed from the seventh day of storage for all temperatures at which they were stored, but the greatest 


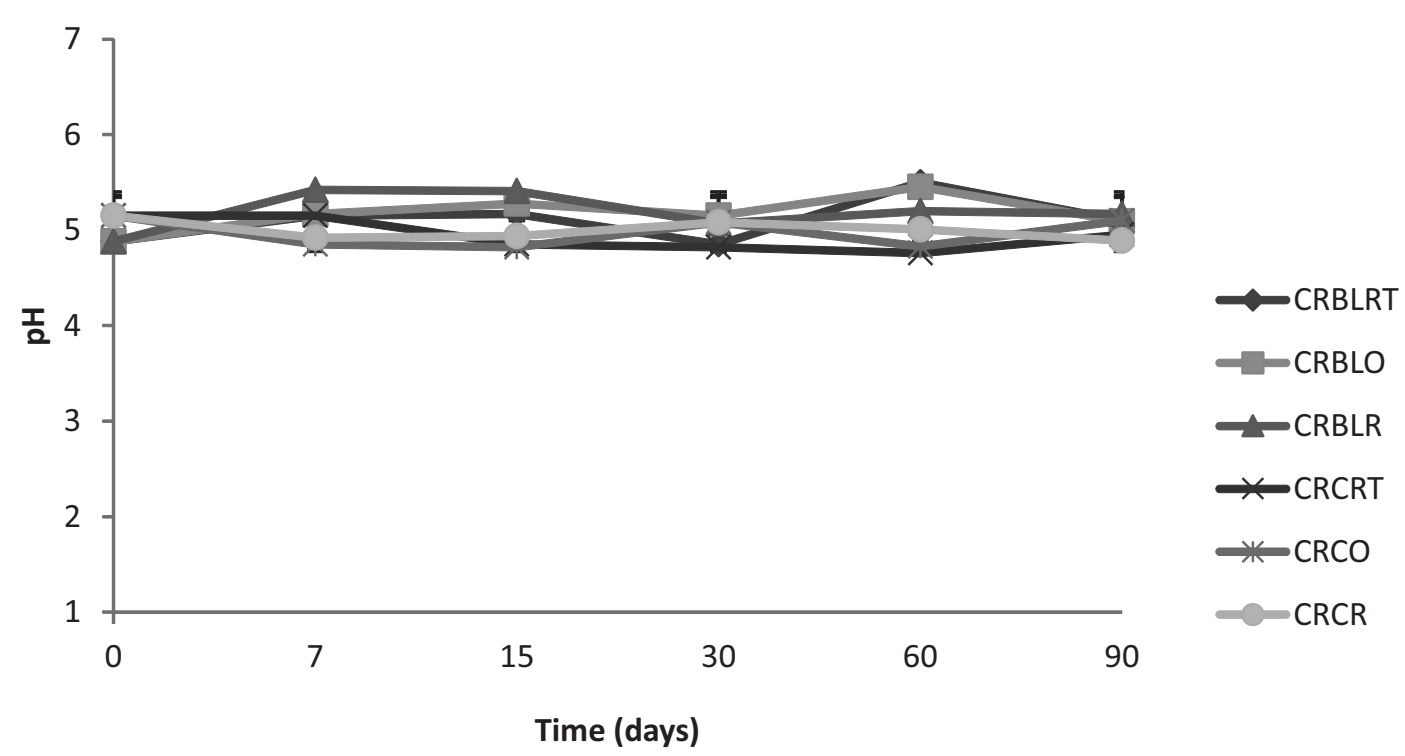

FIGURE 1 - pH of the cream formulations with and without calendula extract during the stability testing period; (CRBLRT - blank cream room temperature; CRBLO - blank cream oven; CRBLR - blank cream refrigerator; CRCRT - calendula cream room temperature; $\mathrm{CRCO}$ - calendula cream oven; CRCR - calendula cream refrigerator) (ANOVA, $p>0.05) .(n=3)$.

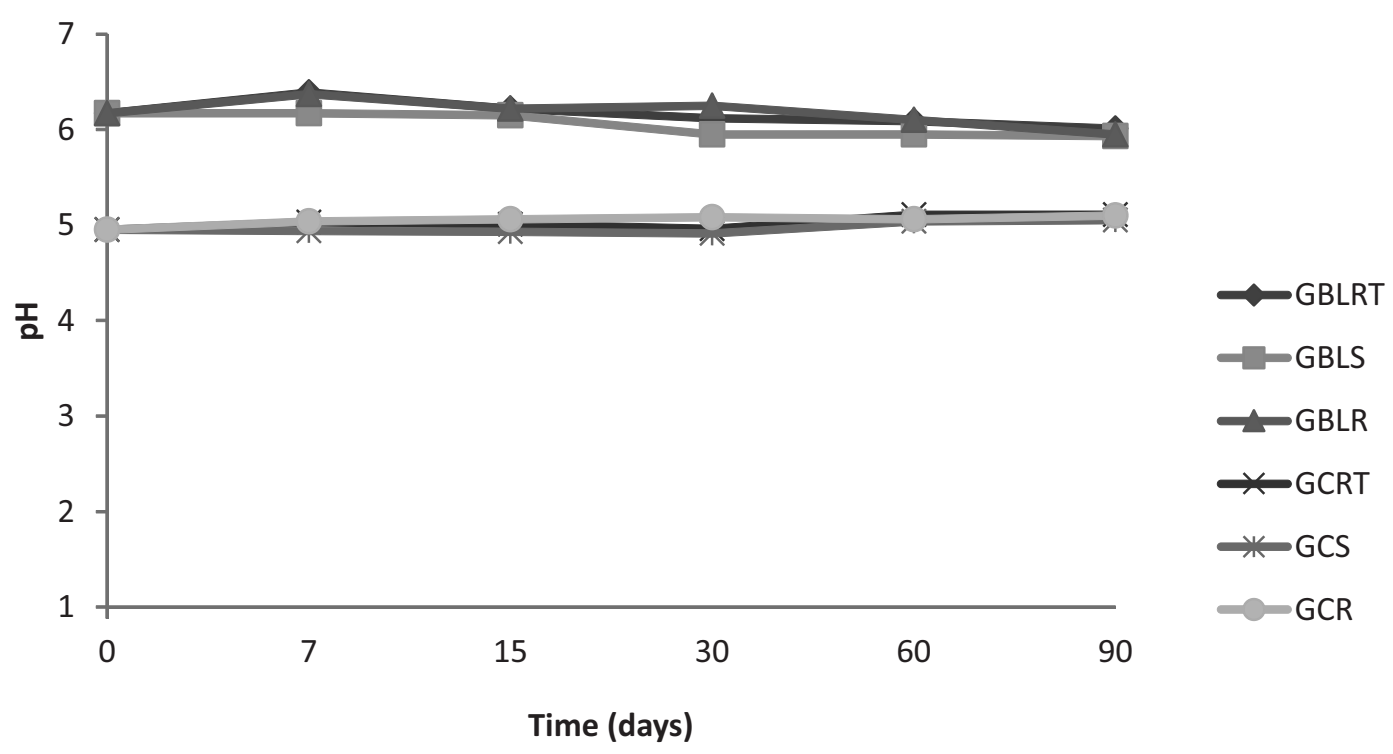

FIGURE 2 - pH of the gel formulations with and without calendula extract during the stability testing period; (GBLRT - blank gel room temperature; GBLO - blank gel oven; GBLR - blank gel refrigerator; GCRT - calendula gel room temperature; GCO calendula gel oven; GCR - calendula gel refrigerator) (ANOVA, tukey test, $p<0.05)$. $(n=3)$.

decrease was found in the oven sample kept at $50{ }^{\circ} \mathrm{C}$. A significant difference was observed when comparing the different samples with blanks $(p<0.05)$. It was also observed that cream samples had lower viscosity variations as compared to the gels, corroborating the results of a similar study by Mariotti and Frasson (2011), where cream and gel formulations containing strawberry extract were evaluated. These variations are expected, since it is known generally that viscosity directly influenced by temperature variations.
Elevated temperatures, for example, can accelerate chemical reactions, altering the activity of the components, viscosity, appearance, color, and formulation odor. Thus, a physical-chemical evaluation is necessary, because changes in the formulation's structure are sometimes not visually perceptible (ANVISA, 2004; Mariotti, Frasson, 2011).

The values obtained for spreadability for CRBL, CRC, GBL and GC (by weight applied) are represented in Figures 5 and 6. 


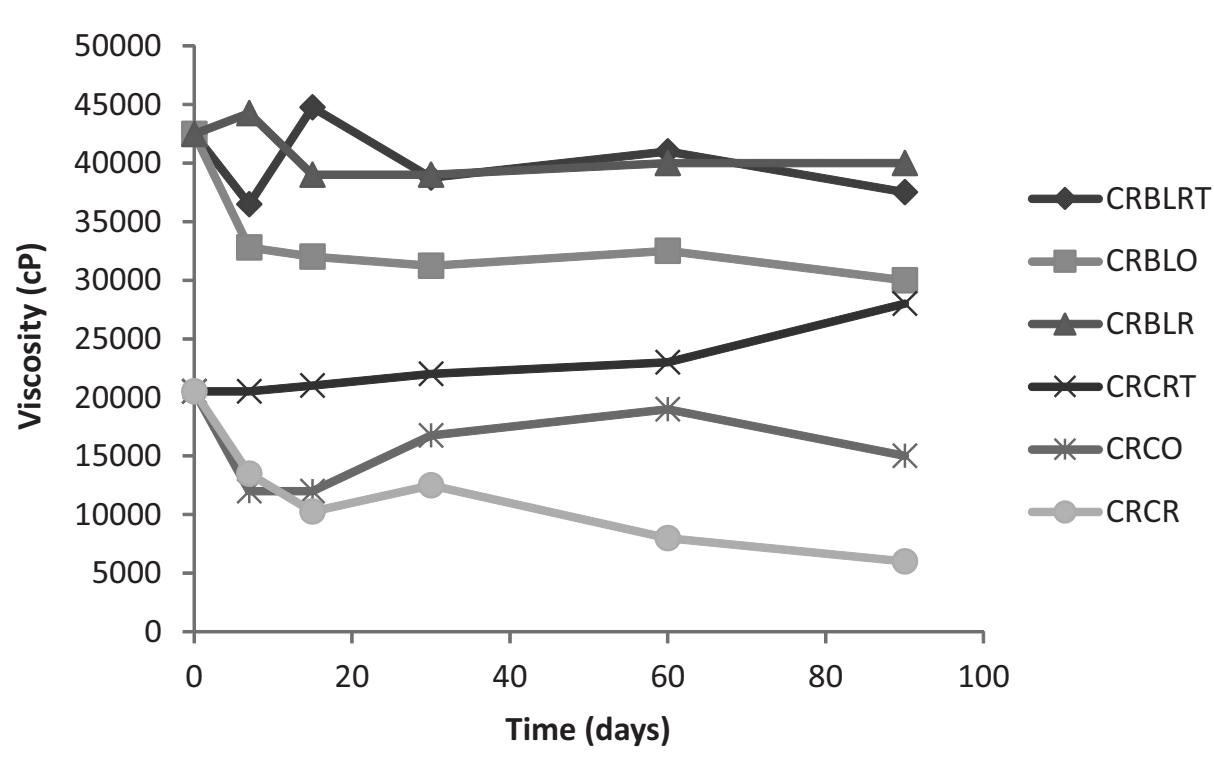

FIGURE 3 - Determination of the viscosity of the cream formulations with, and without calendula extract during the stability testing period; (CBLRT - blank cream room temperature; CRBLO - blank cream oven; CRBLR - blank cream refrigerator; CRCRT calendula cream room temperature; $\mathrm{CRCO}$ - calendula cream oven; CRCR - calendula cream refrigerator) (ANOVA, Tukey test, $p<0.05) .(n=3)$.

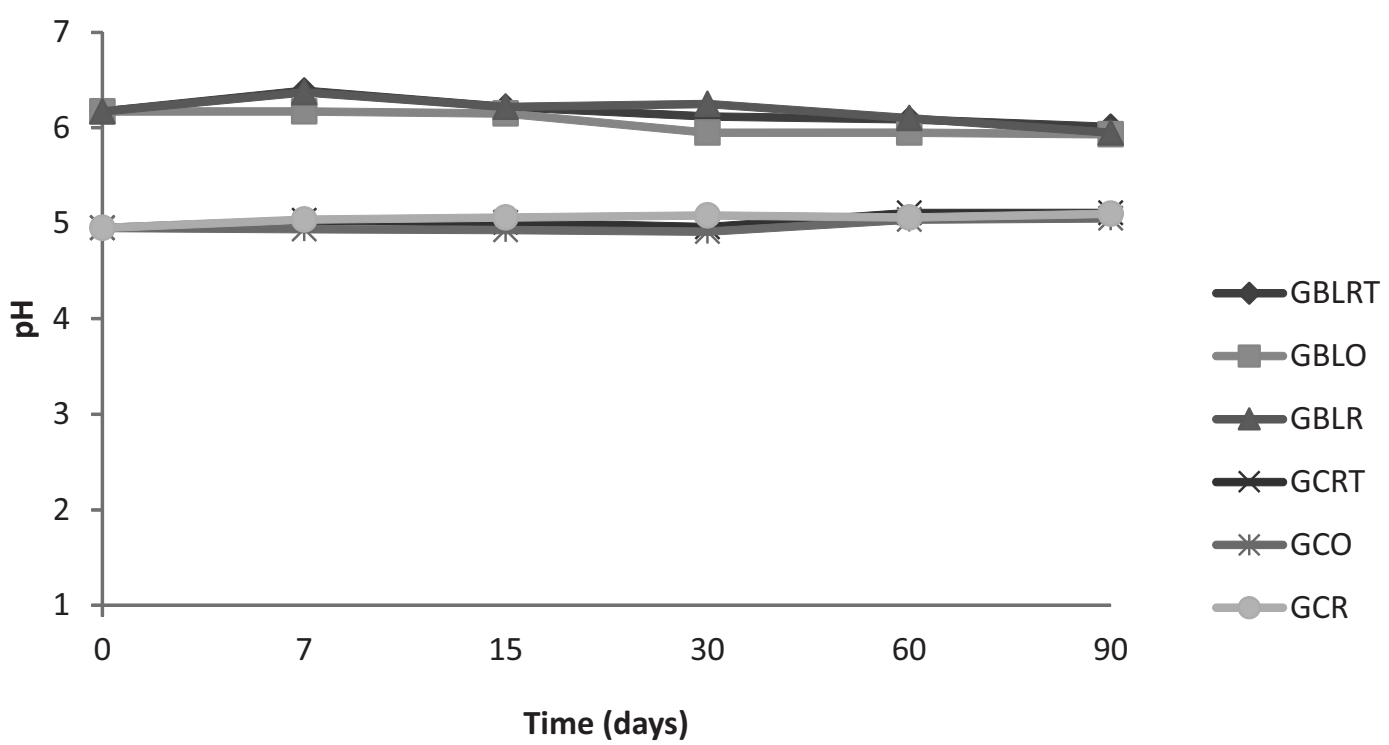

FIGURE 4 - Determination of the viscosity of the gel formulations with and without calendula extract during the stability testing period; (GBLRT - blank gel room temperature; GBLO - blank gel oven; GBLR - blank gel refrigerator; GCRT - calendula gel room temperature; GCO - calendula gel oven; GCR - calendula gel refrigerator) (ANOVA, Tukey test, $p<0.05) .(n=3$ ).

The spreadability factor $(\mathrm{S} f)$ was represented in the Table VI.

Spreadability consists in the expansion of a semi solid formulation on a surface after a certain time, and its determination is important because topical products should be easy to apply on the skin surface (Borghetti, Knorst, 2006).

The formulation's spreadability results showed differing behaviors during storage, and the gels stored at oven temperature showed higher values. Gel and cream formulations, in comparison with their blanks, showed significant differences $(p<0.05)$. Spreadability factor calculations demonstrated that GCO90 had the highest spreadability factor, and CRCRT90, the lowest; however, the difference was significant $(p<0.05)$. The factor is used to calculate the spreadability difference between formulations (Fontana et al., 2011). Variations in spreadability are due to differences in temperatures at 


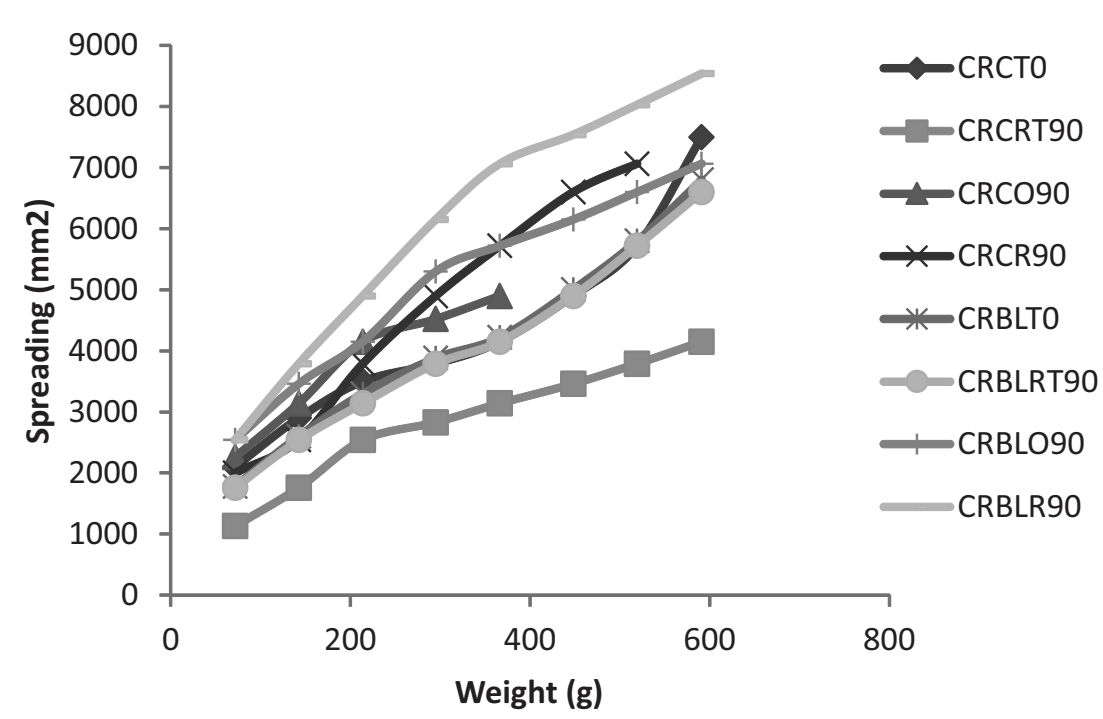

FIGURE 5 - Determination of the spreadability of the cream formulations with and without calendula extract during the stability (CRBLRT - blank cream room temperature; CRBLO - blank cream oven; CRBLR - blank cream refrigerator; CRCRT - calendula cream room temperature; $\mathrm{CRCO}$ - calendula cream oven; $\mathrm{CRCR}$ - calendula cream refrigerator) (ANOVA, Tukey test, $p<0.05$ ). $(n=3)$.

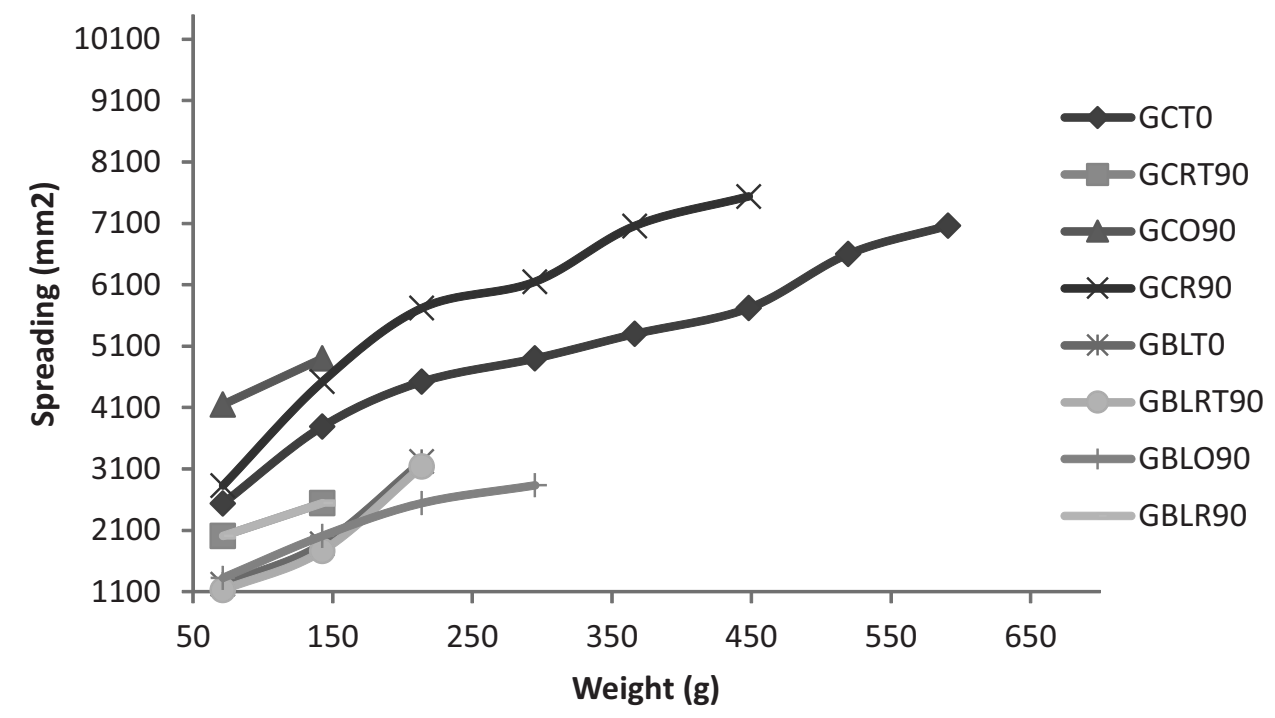

FIGURE 6 - Determination of the spreadability of the gel formulations with and without calendula extract during the stability (GBLRT - blank gel room temperature; GBLO - blank gel oven; GBLR - blank gel refrigerator; GCRT - calendula gel room temperature; GCO - calendula gel oven; GCR - calendula gel refrigerator) (ANOVA, Tukey test, $p<0.05) .(n=3)$.

which the samples are tested, and for any formulation, the lower the viscosity, the greater its spreadability. This was seen in this study, where the gel samples had higher spreadability, and a lower viscosity as compared to the cream samples.

Antioxidant in vitro capacity results using the DPPH method in CRC are shown in Figure 7, and GC are represented in Figure 8. $\mathrm{IC}_{50}$ is represented in the Table VII.

The DPPH free radical method is easy, fast, and widely used for evaluation of the antioxidant potential of many substances. It is a free radical producing violet staining in ethanol (Mensor et al., 2001). In the presence of antioxidant molecules, its radical is reduced, causing a decrease in color intensity, which can be measured spectrophotometrically (Iha et al., 2008). The results for evaluation of antioxidant capacity in formulations of CRC at time zero, and at the end of 90 days of storage for different temperature conditions show that the formulations exhibited antioxidant capacity superior than $50 \%$ at concentrations of 10 and $20 \mathrm{mg} / \mathrm{mL}$. The refrigerator stored formulation showed the same capacity from $5 \mathrm{mg} / \mathrm{mL}$. There were significant differences between 
TABLE VI - Determination of spreadability factor $(\mathrm{S} f)$ in all formulations in function of total area $\left(\mathrm{mm}^{2}\right)$ and total weight $(\mathrm{g})$

\begin{tabular}{lccc}
\hline Formulations & Total $\mathbf{a r e a}\left(\mathbf{m m}^{\mathbf{2}}\right)$ & Total Weight $\mathbf{( g )}$ & $\mathbf{S} \boldsymbol{f}\left(\mathbf{m m}^{\mathbf{2}} \mathbf{g}^{-\mathbf{1}}\right) \pm$ SD \\
\hline CRCT0 & 6600 & 591.1 & $11.16 \pm 0.34^{*}$ \\
CRCRT90 & 4150 & 591.1 & $7.02 \pm 0.42^{*}$ \\
CRCO90 & 4900 & 366.4 & $13.37 \pm 0.04^{*}$ \\
CRCR90 & 7065 & 519.2 & $13.60 \pm 0.50^{*}$ \\
CRBLT0 & 6800 & 591.1 & $11.50 \pm 0.08^{*}$ \\
CRBLRT90 & 6600 & 591.1 & $11.16 \pm 0.17^{*}$ \\
CRBLO90 & 7065 & 591.1 & $11.95 \pm 0.23^{*}$ \\
CRBLR90 & 8540 & 591.1 & $14.44 \pm 0.32^{*}$ \\
GCT0 & 7065 & 591.1 & $11.95 \pm 0.09 *$ \\
GCR90 & 10170 & 519.2 & $19.58 \pm 0.15^{*}$ \\
GCO90 & 4900 & 142.5 & $34.37 \pm 0.28^{*}$ \\
GCR90 & 448.0 & $16.82 \pm 0.22^{*}$ \\
GBLT0 & 7540 & 213.7 & $15.06 \pm 0.31^{*}$ \\
GBLRT90 & 3220 & 213.7 & $14.68 \pm 0.07^{*}$ \\
GBLO90 & 3140 & 295.0 & $9.60 \pm 0.44^{*}$ \\
GBLR90 & 2833 & 142.5 & $17.83 \pm 0.25^{*}$ \\
\hline
\end{tabular}

Results are expressed as mean \pm relative standard deviation (RSD). (ANOVA, $p<0.05) .(n=3)$. ${ }^{*}$ All samples showed significant differences (in comparison to the blanck, and to each other)

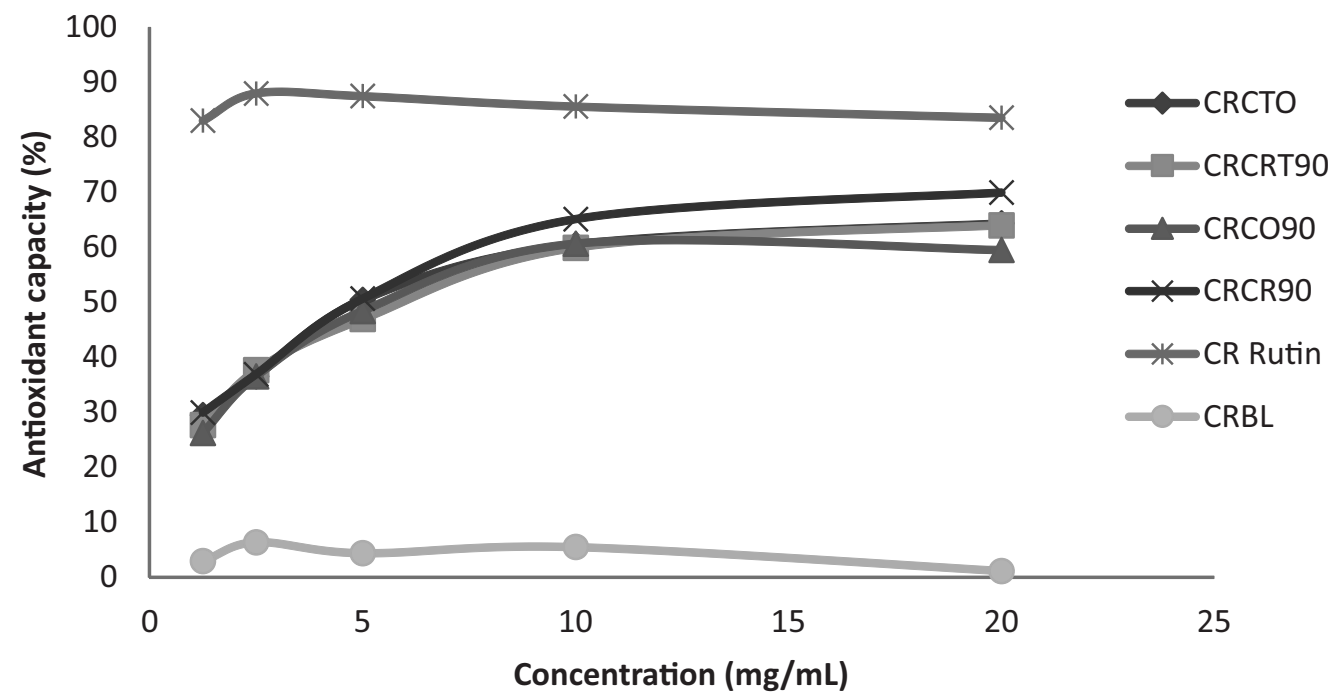

FIGURE 7 - Antioxidant capacity of cream with calendula extract during the period of stability testing. (CRCT0 - calendula cream zero time; CRCRT90 - calendula cream room temperature after 90 days; CRCO90 - calendula cream oven after 90 days; CRCR90 - calendula cream refrigerator after 90 days; CR Rutin - rutin cream-standard; CRBL - blank cream ). (ANOVA,Tukey test, $p<0.05) .(n=3)$.

formulations and the positive and negative standards $(p<0.05)$, but between samples, significant differences were not observed $(p>0.05)$. The formulations showed good antioxidant activity, however, the antioxidant capacity shown by the standard was higher $(82.99 \%$ for the lowest concentration).

$\mathrm{GC}$ formulations preserved at refrigerator temperature showed the best antioxidant capacity 


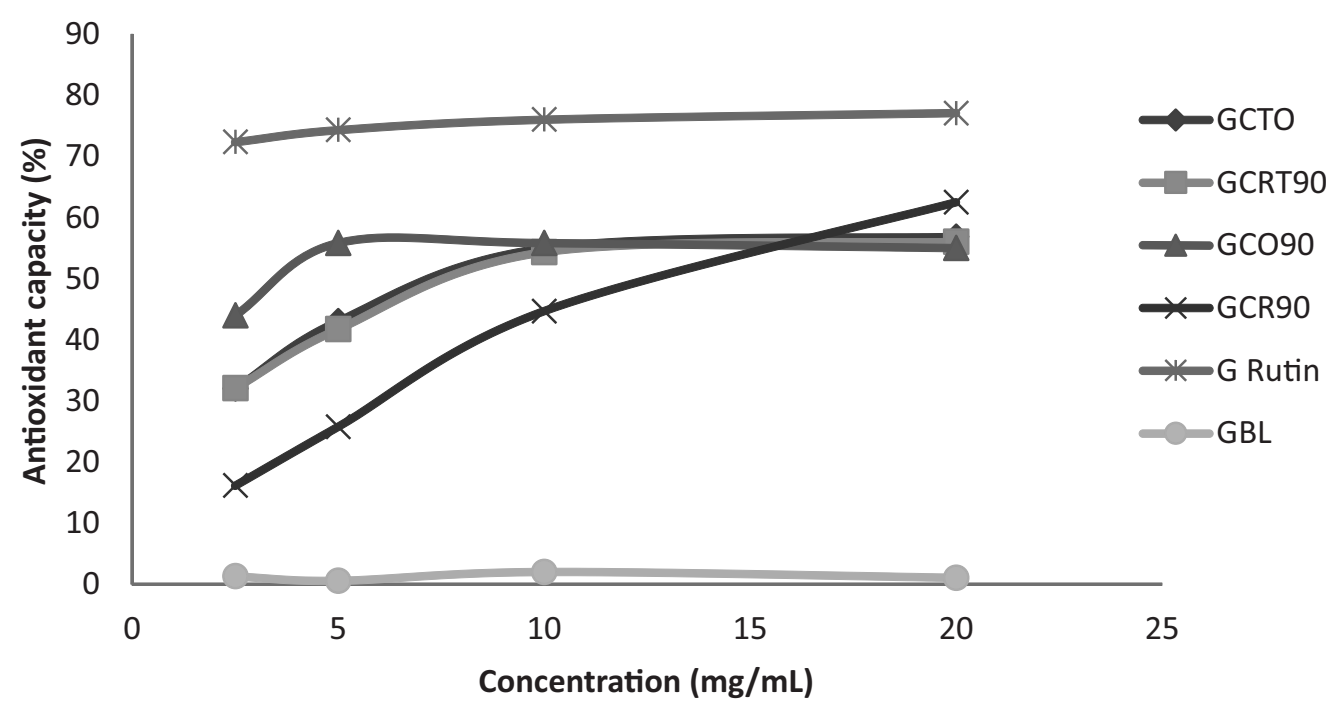

FIGURE 8 - Antioxidant capacity in gel with extract of Calendula during the period of stability testing (GCT0 - calendula gel zero time; GCRT90 - calendula gel room temperature after 90 days; GCO90 - calendula gel oven after 90 days; GCR90 - calendula gel refrigerator after 90 days; CR Rutin - rutin cream- standard; GBL - blank gel). (ANOVA, Tukey test, $p<0.05)$. $(n=3)$.

TABLE VII - $\mathrm{IC}_{50}$ for cream and gel formulations during the period of stability (T0 - Time zero; RT- Room temperature; O- oven; R-Refrigerator)

\begin{tabular}{lcccc}
\hline Formulation/ Time & $\begin{array}{c}\text { T } 0 \pm \text { SD } \\
(\mathbf{m g} / \mathbf{m L})\end{array}$ & $\begin{array}{c}\text { RT90 } \pm \mathbf{S D} \\
\mathbf{( m g} / \mathbf{m L})\end{array}$ & $\begin{array}{c}\mathbf{O 9 0} \pm \mathbf{S D} \\
\mathbf{( m g} / \mathbf{m L})\end{array}$ & $\begin{array}{c}\mathbf{R 9 0} \pm \mathbf{S D} \\
(\mathbf{m g} / \mathbf{m L})\end{array}$ \\
\hline CRC & $4.92 \pm 0.01^{*}$ & $5.46 \pm 0.011$ & $5.17 \pm 0.013$ & $4.88 \pm 0.012^{*}$ \\
CR rutin & $0,74 \pm 0.02$ & & & \\
GC & $7.09 \pm 0.03$ & $6.73 \pm 0.026$ & $12.46 \pm 0.012$ & $13.74 \pm 0.018$ \\
G rutin & $0,81 \pm 0.034$ & & & \\
\hline
\end{tabular}

Results are expressed as mean \pm standard deviation (SD). (ANOVA, Tukey test, $(p<0.05) .(n=3) *$ No significant differences.

at a concentration of $20 \mathrm{mg} / \mathrm{mL}$, and the oven kept sample showed a slight decline of activity for the same concentration. According to Lange, Heberlé, Milão (2009) increases in temperature can cause losses of antioxidant capacity by speeding up chemical reactions in the formulations. Baby et al. (2008) reports that higher temperatures favor the deterioration of phenolic compounds and thus flavonoids since these are sensitive to hydrolysis, ultraviolet radiation, high temperatures, and metals. Both formulations stored for 90 days in the oven might well show antioxidant capacity reductions, thru depletion of these compounds. There were significant differences between formulations and the positive and negative standards $(\mathrm{p}<0.05)$, but between samples, significant differences were not observed $(p>0.05)$. The antioxidant activity shown by the standard was higher than that of the gel formulations $(68.44 \%$ for the lowest concentration).

In general, the cream samples obtained better results for antioxidant capacity as compared to the gel samples.
This might have occurred because BHT, which is an antioxidant, was added to the cream base formulation. This component was not added to gel formulations.

The inhibitory concentration $\left(\mathrm{IC}_{50}\right.$ ) represents the amount of antioxidant substance necessary to decrease the initial DPPH concentration by $50 \%$. The higher the consumption of DPPH by the sample, the lower its $\mathrm{IC}_{50}$, and the higher its antioxidant activity will be (Mariotti, Frasson, 2011). For cream formulations, the lowest $\mathrm{IC}_{50}$ was observed for the CRCR. Significant differences were observed $(p<0.05)$ between samples, except for CRCT0 and CRCR90, where this difference was not significant $(p>0.05)$. For gel formulations there were significant differences between samples $(p<0.05)$. The lowest $\mathrm{IC}_{50}$ were observed in the samples GCT0 and GCRT90. The GCO90 and GCR90 samples had the higher $\mathrm{IC}_{50}$, but these results were considered good when compared to the data in the literature, where cream and gel formulations containing strawberry extract were evaluated for their antioxidant capacities. In this study, $\mathrm{IC}_{50}$ values of 35.97 
TABLE VIII - Determination of in vitro Sun Protection Factor (SPF) cream and gel formulations during stability testing (T0 - time zero; RT - room temperature; $\mathrm{O}$ - oven, $\mathrm{R}$ - refrigerator)

\begin{tabular}{lcccc}
\hline Formulation/ Time & T0 \pm SD & RT \pm SD & O \pm SD & R \pm SD \\
\hline CRC & $1.75 \pm 0.05$ & $1.75 \pm 0.33$ & $1.73 \pm 0.18$ & $1.71 \pm 0.29$ \\
CROM & $4.28 \pm 0.01$ & & & \\
GC & $1.75 \pm 0.26$ & $1.74 \pm 0.13$ & $1.74 \pm 0.09$ & $1.72 \pm 0.36$ \\
GOM & $4.44 \pm 0.13$ & & & \\
\hline
\end{tabular}

$\mathrm{CROM}=$ octylmetoxinamato cream; $\mathrm{GOM}=$ octylmetoxinamato gel. Results are expressed as mean \pm standard deviation (SD). (ANOVA, $p>0.05) .(n=3)$.

and $37.42 \mathrm{mg} / \mathrm{mL}$ were obtained for the oven kept cream and refrigerator kept cream, respectively, and 30.77 and $26.66 \mathrm{mg} / \mathrm{mL}$ were obtained for the gel under the same conditions of temperature (Mariotti, Frasson, 2011). We observed that the formulations showing the best results for antioxidant capacity were the cream with calendula kept in refrigeration, and gel with calendula at time zero and maintained at room temperature.

The results for the evaluation of in vitro Sun Protection Factor (in vitro SPF) in CRC and GC are shown in Table VIII.

For a sunscreen to reach the market, ingredients are necessarily incorporated into a vehicle, and this association is then called the sunscreen (Flor, Davolos, Correa, 2007). Currently, there has been great interest in using plant compounds in sunscreens, especially when they exhibit antioxidant activity (Polonini, Raposo, Brandão, 2011). Thus, flavonoids, tannins, and other phenolic compounds are studied in relation to photoprotective capacity, once they present absorption in the ultraviolet region (Rosa et al., 2008; Violante et al., 2009). Since the extract of C. officinalis present phenolic compounds in its composition, cream and gel formulations were evaluated for this capacity. The results showed an SPF of about 1.75 for all formulations, not showing significant differences during the storage times $(p>0.05)$. Yet compared with the standard, the difference was significant $(p<0.05)$. The formulations stored under different temperature conditions were tested and it was observed that this did not directly affect the SPF measurements since they were unchanged until 90 days of storage. However, according to RDC 237 of 22/08/2002 (BRASIL, 2002), for a product to be suitable for use in sunscreens, it must exhibit an SPF greater than or equal to 2 .

For the Mansour method SPF determination, dilutions of the samples are used in solvents such as ethanol, methanol, and isopropanol for the determination of organic filters. Thus, the method has a limitation in determining the SPFs of formulations having inorganic filters because they are not soluble in the solvents employed. The method has the advantages of speed, low cost, and non-exposure of volunteers, which is necessary for in vivo tests. In vivo techniques are complex and expensive, thus, in vitro tests are very importante, because they are used as screening tests during the development of cosmetic formulations (Velasco et al., 2011).

Thus, the formulations do not conform to this parameter, and cannot be used for their sunscreening capacity.

Mishra, Mishra and Chattopadhyay (2012) determined the FPS of cream formulations containing essential oil from marigold flowers, using the spectrophotometric method developed by Mansur as well. In their study, a value of $14.84 \pm 0.16$ was obtained suggesting that this extract can be used as a sunscreen.

The low SPF results obtained from the leaves of calendula may be well related to the extraction method used.

\section{CONCLUSION}

Samples of cream and gel containing hydroethanolic extracts from Calendula officinalis L. showed good physical and chemical stability when considering that the analyzed parameters remained within established standards, and did not undergo significant changes. The cream formulations retained better characteristics than the gel formulations, except for spreadability, which was higher for the gels. For photo-protective capacity, the formulations did not differ under different storage conditions. However, considering the results, and in accordance with Brazilian regulation, they cannot be used as stand-alone photo-protectives. The antioxidant capacity evaluation did not show significant variations, demonstrating good in vitro activity. Further in vivo antioxidant activity studies are suggested, and photoprotective activity may be explored as a possible enhancement to the SPF of synthetic sunscreens. 


\section{ACKNOWLEDGEMENTS}

The authors thank the Quality Control Laboratory of the Franciscan University Center - UNIFRA (Santa Maria- Brazil).

\section{REFERENCES}

AGATONOVIC-KURSTRIN, S.; LOESHER, C.M. Qualitative and quantitative high performance thin layer chromatography analysis of Calendula officinalis using high resolution plate imaging and artificial neural network data modeling. Anal. Chim. Acta., v.798, n.10, p.103-108, 2013.

AGÊNCIA NACIONAL DE VIGILÂNCIA SANITÁRIA. ANVISA. Guia de Estabilidade de Produtos Cosméticos/ Agência Nacional de Vigilância Sanitária.1.ed. Brasília: ANVISA, 2004.

AGÊNCIA NACIONAL DE VIGILÂNCIA SANITÁRIA. ANVISA. Formulário Nacional/Ministério da Saúde. Brasília: Ministério da Saúde, 2005.

BABY, A.R.; HAROUTIOUNIAN-FILHO, C.A.; SARRUF, F.D.; TAVANTE-JUNIOR, C.R.; PINTO, C.A.S.O.; ZAGUE, V.; ARÊAS, E.P.G.; KANEKO, T.M.; VELASCO, M.V.R. Estabilidade e estudo de penetração cutânea in vitro da rutina veiculada em uma emulsão cosmética através de um modelo de biomembrana alternativo. Braz. J. Pharm. Sci., v.44, n.2, p.233-248, 2008.

BRASIL. Resolução RDC n.237 de 02 de agosto de 2002. Diário Oficial da União, Brasília, 26 agosto, 2002.

BORGHETTI, G.S.; KNORST, M.T. Desenvolvimento e avaliação da estabilidade física de loções $\mathrm{O} / \mathrm{A}$ contendo filtros solares. Braz. J. Pharm. Sci., v. 42, n. 4, p. 531-537, 2006

BUTNARIU, M.; CORADINI, C.Z. Evaluation of Biologically Active Compounds from Calendula officinalis Flowers using Spectrophotometry. Chem. Cent. J., v.6, n.35, p.1-7, 2012.

CITADINI-ZANETTE, V.; NEGRELLE, R.R.B.; BORBA, E.T. Calendula officinalis L. (ASTERACEAE): Aspectos Botânicos, ecológicos e usos. Rev. Visão Acad., v.13, n.1, p.6-23, 2012.

FLOR, J.; DAVOLOS, M.R.; CORREA, M.A. Protetores solares. Quim. Nova, v.30, n.1, p.153-158, 2007.
FONSECA, Y.M.; CATINI, C.D.; VICENTINI, F.T.M.C.; NOMIZO, A.; GERLACH, R.F.; FONSECA, M.J.V. Protective effect of Calendula officinalis extract against UVB-induced oxidativestress in skin: Evaluation of reduced glutathione levels and matrix metalloproteinase secretion. J. Ethnopharmacol., v.127, n.3, p.596-601, 2010.

FONTANA, M.C.; REZER, J.F.; CORADINI, K.; LEAL, D.B.; BECK, R.C. Improved efficacy in the treatment of contact dermatitis in rats by a dermatological nanomedicine containing clobetasol propionate. Eur. J. Pharm. Biopharm., v.79, n.2, p.241-249, 2011.

GONÇALVES, G.M.S.; CAMPOS, P.M.B.G.M. Aplicação de métodos de biofísica no estudo da eficácia de produtos dermocosméticos. Braz. J. Pharm. Sci., v.45, n.1, p.2-10, 2009.

IHA, S.M.; MIGLIATO, K.F.; VELlOSA, J.C.R.; SACRAMENTO, L.V.S.; PIETRO, R.C.L.R.; ISAAC, V.L.B.; BRUNETTI, I.L.; CORRÊA, M.A.; SALGADO, H.R.N. Estudo fitoquímico de goiaba (Psidium guajava L.) compotencial antioxidante para o desenvolvimento de formulação fitocosmética. Braz. J. Pharmacog., v.18, n.3, p.387-393, 2008.

ISAAC, V.L.B.; CEFALI, L.C.; CHIARI, B.G., OLIVEIRA, C.C.L.G.; SALGADO, H.R.N.; CORREAA, M.A. Protocolo para ensaios físico-químicos de estabilidade de fitocosméticos. Rev. Ciênc. Farm. Básica Apl., v.29, n1, p.81-96, 2008.

KNORST, M.T. Desenvolvimento tecnológico de forma farmacêutica plástica contendo extrato concentrado de Achyrocline satureioides. Lam. DC. Compositae. Porto Alegre, 1991. 228 p. [Dissertation of Master degree de Mestrado. Faculty of Pharmaceutical Sciences. Federeal University Federal of Rio Grande do Sul].

LANGE, M.K.; HEBERLÉ, G.; MILÃO, D. Avaliação da estabilidade e atividade antioxidante de uma emulsão base não-iônica contendo resveratrol. Braz. J. Pharm. Sci., v.45, n.1, p.145-151, 2009.

MANSUR, J.S.; BREDER, M.N.R.; MANSUR, M.C.A.; AZULAY, R.D. Determinação do fator de proteção solar por espectrofotometria. An. Bras. Dermatol., v.61, n.3, p.121-124, 1986. 
MARIOTTI, D.; FRASSON, A.P.Z. Avaliação da estabilidade e atividade antioxidante de formulações cosméticas contendo extrato etanólico dos frutos de Fragaria vesca L. (morango). Infarma, v.23, n.3/4, 2011.

MENSOR, L.L.; MENESES, F.S.; LEITÃO, G.G.; REIS, A.S.; SANTOS, T.C.; COUBE, C.S.; LEITÃO, S.G. Screening of Brazilian plant extract for antioxidant acticity by the use of DPPH free radical method. Phytother. Res., v.15, n.2, p.127-130, 2001.

MISHRA, A.K.; MISHRA, A.; CHATTOPADHYAY, P. Assessment of in vitro Sun Protection Factor of Calendula officinalis L. (Asteraceae) essential oil formulation. J. Young Pharm., v.4, n.1, p.17-21, 2012.

POLONINI, H.C.; RAPOSO, N.R.B.; BRANDÃO, M.A.F. Fotoprotetores naturais como instrumento de ação primária na prevenção do câncer de pele. Rev. APS, v.14, n.2, p.216223,2011 .

RIBEIRO, C. Cosmetologia aplicada a dermoestética. 2. Ed. São Paulo: Pharmabooks, 2010.

ROSA, M.B.; OLIVEIRA, T.G.; CARVALHO, C.A.; SILVA, F.D.; CARVALHO, L.M.; NASCIMENTO, P.C.; PERES, R.L. Estudo espectrofotométrico da atividade fotoprotetora de extratos aquosos de Achillea millefolium, Brassica oleracea var. capitata, Cyperus rotundus, Plectranthus barbatus, Porophyllum ruderale (jacq.) cass e Sonchus oleraceus. Rev. Eletrôn. Farm., v.5, n.1,p.101-110, 2008.
SAYRE, R.M.; AGIN, P.P.; LEVEE, G.J.; MARLOWE, E. Comparison of in vivo and in vitro testing of sunscreening formula. Photochem. Photobiol., v.29, n.3, p.559-566, 1979.

SIMÕES, C.M.O.; SCHENKEL, E.P.; GOSMANN, G.; MELLO, J.C.P.; MENTZ, L.A.; PETROVICK, P.R. Farmacognosia, da planta ao medicamento. 6.ed. Porto Alegre: Editora UFRGS, 2010. 1104 p.

SOUZA, F.P.; CAMPOS, G.R.; PACKER, J.F. Determinação da atividade fotoprotetora e antioxidante em emulsões contendo extrato de Malpighia glabra L. - Acerola Rev. Ciênc. Farm. Básica Apl., v.34, n.1, p.69-77, 2013.

VELASCO, M.V.R.; BALOGH, T.S.; PEDRIALI, C.A.; SARRUF, F.D.; PINTO, C.A.S.O.; KANEKO, T.M.; BABY, A.R. Novas metodologias analíticas para avaliação da eficácia fotoprotetora (in vitro) - revisão. Rev. Ciênc. Farm. Básica Apl., v.32, n. 1, p.27-34, 2011.

VIOLANTE, I.M.P.; SOUZA, I.M.; VENTURINI, C.L.; RAMALHO, A.F.S.; SANTOS, R.A.N.; FERRARI, M. Avaliação in vitro da atividade fotoprotetora de extratos vegetais do cerrado de Mato Grosso. Braz. J. Pharmacog., v.19, n.2A, p.452-457, 2009.

Received for publication on $24^{\text {th }}$ January 2014 Accepted for publication on $07^{\text {th }}$ January 2015 
